MONTANA DEPARTMENT OF FISH, WILDLIFE, AND PARKS

FISHERIES DIVISION

JOB PROGRESS REPORT

STATE: Montana

PROJECT TITLE: Statewide Fisheries Investigations

JOB TITLE: Northcentral Montana Coldwater Stream Ecosystems

\title{
1998 Annual Report
}

\begin{abstract}
A total of 13 streams were inventoried during the report period in the Choteau area. Westslope cutthroat trout were introduced above a natural barrier in a fishless reach of the South Fork of Dupuyer Creek. Cutthroat trout were collected from four streams for genetic testing. A fish kill was documented in late July 1998 in Cut Bank Creek. In 1997, Big Spring Creek estimates of rainbow and brown trout 10 inches and larger were similar to those seen for 1995 and 1996. In 1998, Big Spring Creek estimates of rainbow trout 10 inches and larger in the Tresch Section and brown trout 10 inches and larger in the Burleigh and Tresch (Old Carroll Trail) sections increased from those seen in the past few years. No estimate of brown trout population levels was obtained from the Brewery Flats Section in 1998. Estimates of rainbow trout 10 inches and larger declined in the Burleigh and Brewery Flats sections in 1998. Sediment cores taken on Big Spring Creek in 1997 at the Lower State Hatchery, the Burleigh Fishing Access Site (FAS) and the Tresch (Old Carroll Trail FAS) showed no significant differences between sites for estimated rainbow trout embryo survival. Cores taken from active redds had higher estimated survival than those taken from undefined areas. Natural reproduction of smallmouth bass and rainbow trout was found in Warm Spring Creek. In 1997, the point estimate for rainbow trout 9 inches and longer was 165 per mile on Warm Springs Creek. Westslope cutthroat were transferred above a waterfall barrier on Lost Creek, approximately doubling their occupied habitat to one mile. Eight other streams in the Lewistown area were surveyed. Rainbow and brown trout catch per unit effort (CPUE) in the Tiber Section of the Marias River was 10.4 and 9.9 fish per hour, respectively, in 1998 . These catch rates were among the highest CPUE since surveys were initiated in 1987. We obtained population and biomass estimates on the Smith and Missouri rivers; results will be presented in a future report. Approximately 147 projects were reviewed under the Natural Streambed and Land Preservation Act while another 37 projects were reviewed under the Stream Preservation Act during 1998.
\end{abstract}

STATE DOCUMENTS COLLECTION

‥? 042002 


\title{
OBJECTIVES
}

1. To identify and monitor the characteristics and trends of fish populations, angler harvest and preferences, and habitat conditions in northcentral Montana coldwater stream ecosystems.

2. Use survey and inventory information to identify management problems and opportunities, then develop and implement management actions to maintain fish populations at levels consistent with habitat conditions or other limiting factors.

3. Review projects proposed by state, federal, and local agencies and private parties which have the potential to affect fisheries resources and aquatic habitats. Provide technical advice or decisions to reduce or mitigate resource damage.

4. Provide landowners and other private parties with technical advice and information to sustain and enhance fisheries resources and aquatic habitat.

5. Enhance public understanding and awareness of fishery and aquatic habitat resources and issues in northcentral Montana through oral and written communication.

6. Maintain and enhance public access to fishery resources in northcentral Montana.

7. To enhance trout populations and trout fishing opportunity in Marias River immediately downstream from Tiber Dam.

\section{PROCEDURES}

\author{
Choteau Area
}

The North Fork of the Sun River above Gibson Reservoir was sampled by hook and line; rainbow and cutthroat trout greater than eight inches were tagged with Floy $T$-tags. The Peterson mark-recapture method (Ricker 1975) was used to estimate the trout population after snorkel observations provided tagged and untagged fish data. The fish populations in other streams were sampled with a backpack shocker. Measurements of all fish sampled include total lengths to the nearest tenth of an inch and weights to the nearest hundredth of a pound. Several streams were cooperatively surveyed with Lewis \& Clark Forest personnel. Cutthroat trout were collected for testing of genetic purity by Dr. Robb Leary at the University of Montana. 


\section{Marias River}

The electroshocking system used on the Lower Marias River to capture trout and mountain whitefish was adapted from Novotny and Priegal (1974). The electroshocking unit was a boom-type mounted on a 14-foot aluminum driftboat powered with a $10 \mathrm{hp}$ outboard motor. Power was supplied by a 5000-watt AC generator. A Coffelt Model VVP-10 rectifying unit produced continuous direct current. Two circular hoops, each with twelve 16 -inch stainless steel droppers, comprised the positive electrode, which was extended six feet in front of the boat. The hull of the boat served as the negative. Output was typically $2-5$ amps, $100-$ 215 volts and a continuous direct current wave form. Fish abundance was measured using catch per unit effort (CPUE) index, expressed as the number of fish caught per hour of sampling effort.

\section{Lewistown Area}

Trout populations on Big Spring Creek were surveyed using a fiberglass drift boat equipped with a mobile electrode and a Coeffelt VVP-15 to rectify AC to straight DC. Power was obtained from a 240 volt generator. Big Spring Creek mark-recapture estimates were analyzed with the MFWP MR-4 program utilizing log-likelihood statistics (MDFWP 1994). Scales were used for age analysis. Rainbow trout were collected, frozen and sent to the Washington Animal Disease Diagnostic Laboratory for testing for whirling disease. Sediment core sampling in Big Spring Creek was done following the methods of Shepard and Graham (1982). Cores were collected by MFWP and the Lewis and Clark National Forest completed the lab work. Percent rainbow trout embryo survival was estimated using the equation for rainbow survival from Irving and Bjornn (1984):

$$
\left(113.6-10.8(X)-0.007(Y)^{2}-0.3(X)^{2}\right) \text {. }
$$

where: $X=$ percent of sediment smaller than $0.85 \mathrm{~cm}$

$Y=$ percent of sediment smaller than $9.5 \mathrm{~cm}$

Fish populations in small streams in the Lewistown area were sampled with a Smith Root Model 12-A battery powered backpack electrofishing unit on the $\mathrm{H}-3$ setting, using a 12Ah 24-volt battery. Population estimates done on small streams followed the methods of Leathe (1983). Streams were electrofished in a downstream direction with a block net at the downstream end. Rainbow trout and smallmouth bass from Warm Springs Creek were tagged with numbered floy tags. MFWP collected surface sediment samples for Polychlorinated Biphenyl (PCB) and hydrocarbon analysis. These samples were analyzed by Energy Laboratories, Inc. of Billings, Montana using Environmental Protection Agency Methods.

\section{Great Falls Area}

Trout populations on the Smith River were surveyed using a fiberglass drift boat equipped with a mobile electrode and a Coeffelt WVP-15 or Mark XXII-M to rectify AC to straight DC. 
Power was obtained from a 240 volt generator. The Missouri River was electrofished at night using two aluminum jet boats. Both boats were equipped with headlights and fixed booms with stainless steel droppers suspended in front of the bow. Electricity from 240 volt portable generators was converted to pulsed or straight DC using Coffelt rectifying units. The only pulsed setting used was the Complex Pulse System (CPS). Rainbow and brown trout populations from the Smith and the Missouri rivers were estimated using the loglikelihood method which generates recapture efficiency curves for estimate production (MDFWP 1994). We analyzed mark-recapture and age data with a MFWP computer program on an IBM-PC compatible microcomputer.

\section{Habitat Protection}

Recommendations and alternatives for projects involving stream banks and channels were made through participation in the Stream Protection Act (SPA) and the Natural Streambed and Land Preservation Act (SB310).

\section{RESULTS}

\section{Choteau Area}

\section{Westslope Cutthroat Trout}

Cutthroat trout were collected from Wrong Creek, Gates Creek, and the North Fork Sun River in the upper North Fork Sun River drainage, and in the Box Canyon area of the North Fork Teton River. Electrophoretic analysis (horizontal starch gel) indicates that the Gates Creek sample is a hybridized population of westslope cutthroat (94.3\%) and rainbow trout $(5.7 \%)$. Test results from the other waters are pending.

Westslope cutthroat trout were transferred from the Middle Fork Dupuyer Creek to a fishless reach above a barrier in the South Fork Dupuyer Creek on June 11, 1998. A total of 46 fish were transported by pack horse and released in the South Fork at the junction of Rival Creek. Approximately three hours lapsed from the time the fish were removed from the irrigation ditch until they were released in the stream. These fish ranged in length from 2.5-7.5 inches and were salvaged from an irrigation ditch that receives diverted water from the Middle Fork Dupuyer Creek. This transfer was proposed in an Environmental Analysis (Hill 1998) and also discussed in an earlier report (Hill et al. 1998).

\section{Sun River}

Rainbow and cutthroat trout populations were sampled in the North Fork Sun River on July 23-25, 1998. Survey crews caught and tagged 96 trout greater than eight inches and averaged a catch rate of $4.2 \mathrm{fish} / \mathrm{hour}$. These fish averaged 10.5 inches in total length (range=17.9-16.2 inches). Due to suspended sediment, snorkel surveys were postponed 
until August 10. Water clarity was still impaired on this date and only five tagged fish were observed. Consequently a reliable population estimate was not obtained and none is presented here.

\section{Miscellaneous Stream Surveys}

A number of streams were surveyed to update district information and the data are on file in the Choteau field office. Streams sampled include Sage Creek in the Sweetgrass Hills, South Fork Sun River above Hoadley Creek, North and South Forks Sun River immediately above Gibson Reservoir, Lange Creek and Big George Creek. Whirling disease samples were also collected from the latter four streams. Results are pending. Approximately 400 grayling were transferred from the Sunny Slope Canal near Fairfield to Tunnel Lake.

\section{Fish Kill}

A fish kill on Cut Bank Creek near Cut Bank, Montana was reported on July 28, 1998. Investigations conducted on July 27-28 revealed several hundred dead fish in an area from the City water treatment intake dam downstream approximately one half mile. Most were mountain whitefish; we also observed a few rainbow trout, mountain suckers and longnose dace.

Temperature, turbidity and $\mathrm{pH}$ are recorded every two hours at the City water treatment plant. Turbidity and $\mathrm{pH}$ were considered within a normal range but temperatures were extremely high. Maximum temperatures slightly exceeding $82^{\circ} \mathrm{F}$ were documented on July 27 and over $80^{\circ} \mathrm{F}$ on July 25 and 26 . These readings occurred for several hours each day, generally from 6:00 to $10: 00$ P.M.

\section{Lower Marias River - Tiber Dam Tailwater}

The Tiber Dam tailwater study area extends over a 21 mile reach of the Lower Marias River from the dam to Circle Bridge at Highway 223. Tiber Reservoir is a water storage reservoir with no hydroelectric power generation. Flows in the river downstream are completely controlled by discharges from the dam.

A trout fishery exists in the 21-mile reach of the Lower Marias River immediately below Tiber Dam and is maintained by coldwater releases from the dam. Prior to 1985 the coldwater fishery existed far below its potential because of inadequate instream flows and periodic surface warmwater releases from the dam (Gardner and Berg 1983). The Montana Fish Wildlife and Parks has recommended a minimum instream flow of $500 \mathrm{cfs}$ be maintained in the niver below Tiber Dam for the trout fishery. A 4-mile survey section was established from Sanford Park to 0.25 miles past Pugsley Bridge to monitor the fish population trends in this reach. 
The trout fishery had improved substantially from 1985 to 1988 probably in response to a better flow and temperature conditions (Gardner 1988). Field studies in 1987 showed marked improvements in trout numbers, sizes, and reproductive success. However, results from the 1988-96 surveys indicated that trout populations had stabilized and declined, and did not continue to improve as anticipated.

A total of 63 rainbow trout, 79 brown trout and 118 mountain whitefish were sampled in the study section while conducting our biannual population trend surveys. Because of the abundant mountain whitefish population in the area only a representative sample of the whitefish shocked were netted and measured for size comparisons (Table 1). Comparisons of these size statistics show that sizes for all three species of salmonids measured in 1998 were equal to (brown trout) or considerably larger than the previous year sampled and the 5 -year average. For both rainbow and brown trout the larger average sizes for 1998 is attributed the strong representation of 15 to 20 inch fish (Figure 1). Yearling trout 6-11 inches (Gardner and Berg 1983) comprised 21 and $16 \%$ of the sample for rainbows and browns; the yearling trout representation was considered better than average. Fifty-eight percent of the mountain whitefish sample was comprised of the 15 to 17 inch-groups and $14 \%$ were from yearling group, 6-11 inches.

Abundance measurements indicate that the 1998 trout numbers in the Tiber section are considerably greater than what was found in 1996. Table 1 shows that rainbow and brown trout catch rates (CPUE) that combined both yearlings and adults were 10.4 and 9.9 fish per hour, respectively, in 1998 compared to the 1996 catch rates of 2.7 and 4.0 fish per hour. The trout catch rates recorded in 1998 were nearly the greatest that have been measured since the trend surveys began in 1987 . These relatively high catch rates occurred only two years following a year (1996) when trend surveys indicated the trout populations were at an all-time low. It is difficult to identify factors that may have attributed to the sudden increase in numbers, however, it is doubtful that natural reproduction in the study section alone accounted for the increase. A couple explanations could be that the additional numbers of trout may have originated from farther downstream or upstream (Tiber Reservoir) areas. Also, it is possible that the trend survey sampling conducted in 1996 may not have been representative of the existing condition.

During the period 1990-94 an attempt was made to improve rainbow trout numbers by stocking with hatchery reared rainbows of wild stock origin. A total of 47,785 fingerling and advanced fingerling rainbow trout were stocked in this section with poor direct results (Tews et al. 1995). Although stocked fish comprised only a small portion of fish sampled in subsequent years, it was believed there could have been a "buffering" benefit for the yearling trout of wild origin, when the stocking rates approached 20,000 trout in the section. In these years, numbers of yearling trout were far greater than normal. It was decided to continue with stocking trout in the study section (4 miles) and 6.5 more miles of river downstream. The plan was to stock 20,000 rainbow trout (Eagle Lake) and 20,000 brown trout 3-5 inch fingerlings for 5 years beginning in 1998. All fish will be adipose fin clipped so that the stocking program can be evaluated. Mavrakis and Yule (1998) evaluated 
Table 1. Size statistics and catch per unit effort (CPUE) for rainbow trout, brown trout, and mountain whitefish sampled in the Tiber Section of the Marias River, Montana, 1987-98.

\begin{tabular}{ccllll}
\hline $1990-1994$ & Maximum & Minimum & 1996 & 1998 \\
5 year & number of & number of & & \\
Average $^{1}$ & fish & $\begin{array}{l}\text { fish } \\
\text { sampled }^{2}\end{array}$ & sampled $^{2}$ & & \\
\hline
\end{tabular}

Rainbow trout

Number of fish

Average total length (inches)

Yearlings CPUE

Adult CPUE

Effort (hours)

87

124

37

37

63

13.2

2.3

17.0

4.9

11.0

$16.1 \quad 17.0$

3.5

6.6

0.2

0.4

3.8

15.2

16.0

2.3

2.3

6.6

8.0

14.0

8.0

Brown trout

Number of fish

94

118

57

57

79

Average total length

(inches)

16.1

17.7

13.9

17.1

17.1

Yearlings CPUE

1.2

2.9

0.2

0.4

2.0

Adult CPUE

5.0

7.9

3.1

3.6

7.9

Effort (hours)

15.2

16.0

8.0

14.0

8.0

Mountain whitefish

Average total length (inches) $^{3}$ 


\section{MARIAS RIVER - TIBER SECTION - 1998}

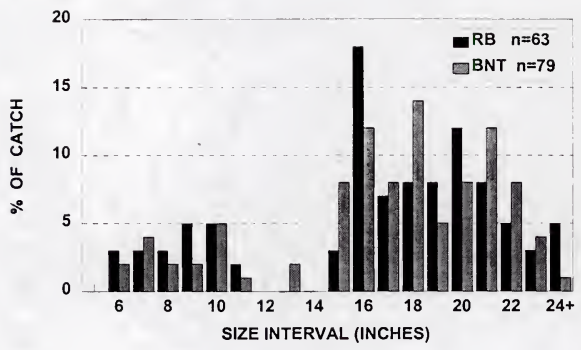

Figure 1. Length Frequencies of rainbow and brown trout sampled in the Tiber Section of the Marias River, Montana in 1998. (RB= rainbow trout; $B N T=$ brown trout).

Wyoming's stocking program for the coldwater sections of the North Platte River, a river of similar size to that of the Marias, and recommended rainbow fingerling stocking rates of 2,500-10,000/mile. They reported favorable results stocking with Eagle Lake rainbows at these densities. The stocking rate for the Marias River in the targeted 10.5 mile reach would be approximately 3,800 trout/mile and is within the range set for the North Platte River. We implemented the stocking plan in 1997, one year before the plan was scheduled to begin, because of the low numbers of trout found in the section during the 1996 survey and the availability of surplus hatchery fish. A total of 11,165 brown trout were stocked in 1997. The 1998 electrofishing survey sampled 16 yearling brown trout of which only 3 had a clipped adipose fin (hatchery fish).

Lewistown Area

\section{Big Spring Creek}

Mark recapture estimates were completed on three sections of Big Spring Creek in August 1997 and 1998. However, due to low numbers of captured and recaptured fish, a brown trout estimate was not obtained from the Brewery Flats section in 1998 (Table 2). In 1997, 
Table 2. Mark recapture statistics from population estimates obtained on Big Spring Creek, Montana during 1997 and 1998. (SD in parenthesis).

\begin{tabular}{|c|c|c|c|c|c|c|c|c|c|}
\hline \multicolumn{10}{|c|}{ Rainbow trout 1997} \\
\hline Section & $\begin{array}{c}\text { Date } \\
\text { Marked }\end{array}$ & $\begin{array}{c}\text { Number } \\
\text { marked }\end{array}$ & $\begin{array}{l}\text { Number } \\
\text { captured }\end{array}$ & $\begin{array}{c}\text { Number } \\
\text { Recaptured }\end{array}$ & $\begin{array}{l}\text { Pooled } \\
\text { (P) }\end{array}$ & $\begin{array}{c}\text { Number } \\
\text { /mile } \\
6-10 \text { inches }\end{array}$ & $\begin{array}{c}\text { Number } \\
\text { /mile } \\
>10 \text { inches }\end{array}$ & $\begin{array}{c}\text { Number } \\
/ \text { mile } \\
>6 \text { inches }\end{array}$ & $\begin{array}{l}\text { Biomass/ } \\
\text { Mile (lbs.) }\end{array}$ \\
\hline Burleigh & $8 / 19$ & 67 & 94 & 15 & 0.66 & $\begin{array}{l}1010 \\
(711)\end{array}$ & $\begin{array}{l}373 \\
(98)\end{array}$ & $\begin{array}{l}1383 \\
(718)\end{array}$ & $\begin{array}{c}437 \\
(128)\end{array}$ \\
\hline $\begin{array}{l}\text { Brewery } \\
\text { Flats }\end{array}$ & $8 / 21$ & 110 & 80 & 21 & 0.44 & $\begin{array}{c}733 \\
(252)\end{array}$ & $\begin{array}{l}268 \\
(36)\end{array}$ & $\begin{array}{l}1001 \\
(255)\end{array}$ & $\begin{array}{l}285 \\
(52)\end{array}$ \\
\hline $\begin{array}{c}\text { Tresch } \\
\text { (Carroll Tr) } \\
\end{array}$ & $8 / 20$ & 342 & 405 & 118 & 0.195 & $\begin{array}{r}932 \\
(87) \\
\end{array}$ & $\begin{array}{r}874 \\
(30) \\
\end{array}$ & $\begin{array}{l}1807 \\
(92) \\
\end{array}$ & $\begin{array}{l}916 \\
(44) \\
\end{array}$ \\
\hline \multicolumn{10}{|c|}{ Rainbow trout 1998} \\
\hline Section & $\begin{array}{c}\text { Date } \\
\text { Marked }\end{array}$ & $\begin{array}{l}\text { Number } \\
\text { marked }\end{array}$ & $\begin{array}{l}\text { Number } \\
\text { captured }\end{array}$ & $\begin{array}{c}\text { Number } \\
\text { Recaptured }\end{array}$ & $\begin{array}{l}\text { Pooled } \\
\text { (P) }\end{array}$ & $\begin{array}{c}\text { Number } \\
\text { /mile } \\
6-10 \\
\text { inches } \\
\end{array}$ & $\begin{array}{c}\text { Number } \\
\text { /mile } \\
>10 \text { inches }\end{array}$ & $\begin{array}{c}\text { Number } \\
/ \text { mile } \\
>6 \text { inches }\end{array}$ & $\begin{array}{l}\text { Biomass/ } \\
\text { Mile (lbs.) }\end{array}$ \\
\hline Burleigh & $8 / 17$ & 108 & 89 & 25 & 0.472 & $\begin{array}{l}157 \\
(37)\end{array}$ & $\begin{array}{l}207 \\
(26)\end{array}$ & $\begin{array}{l}363 \\
(46)\end{array}$ & $\begin{array}{l}176 \\
(27)\end{array}$ \\
\hline $\begin{array}{l}\text { Brewery } \\
\text { Flats }\end{array}$ & $8 / 20$ & 83 & 74 & 18 & 0.595 & $\begin{array}{l}475 \\
(64)\end{array}$ & $\begin{array}{l}218 \\
(15)\end{array}$ & $\begin{array}{c}693 \\
(108)\end{array}$ & $\begin{array}{l}214 \\
(24)\end{array}$ \\
\hline $\begin{array}{c}\text { Tresch } \\
\text { (Carroll Tr) }\end{array}$ & $8 / 19$ & 471 & 429 & 98 & 0.79 & $\begin{array}{l}1105 \\
(88) \\
\end{array}$ & $\begin{array}{l}1639 \\
(70) \\
\end{array}$ & $\begin{array}{l}2744 \\
(113) \\
\end{array}$ & $\begin{array}{l}1464 \\
(87) \\
\end{array}$ \\
\hline \multicolumn{10}{|c|}{ Brown trout 1997} \\
\hline Section & $\begin{array}{c}\text { Date } \\
\text { Marked }\end{array}$ & $\begin{array}{l}\text { Number } \\
\text { marked }\end{array}$ & $\begin{array}{l}\text { Number } \\
\text { captured }\end{array}$ & $\begin{array}{c}\text { Number } \\
\text { Recaptured }\end{array}$ & $\begin{array}{l}\text { Pooled } \\
\text { (P) }\end{array}$ & $\begin{array}{c}\text { Number } \\
\text { /mile } \\
6-10 \text { inches }\end{array}$ & $\begin{array}{c}\text { Number } \\
\text { /mile } \\
>10 \text { inches }\end{array}$ & $\begin{array}{l}\text { Number } \\
\text { /mile } \\
>6 \text { inches }\end{array}$ & $\begin{array}{l}\text { Biomass/ } \\
\text { Mile (lbs.) }\end{array}$ \\
\hline Burleigh & $8 / 19$ & 45 & 52 & 16 & 0.02 & 0 & $\begin{array}{l}127 \\
(20)\end{array}$ & $\begin{array}{l}127 \\
(20)\end{array}$ & $\begin{array}{l}167 \\
(36)\end{array}$ \\
\hline $\begin{array}{l}\text { Brewery } \\
\text { Flats }\end{array}$ & $8 / 21$ & 52 & 49 & 19 & 0.33 & 0 & $\begin{array}{l}187 \\
(23)\end{array}$ & $\begin{array}{l}187 \\
(23)\end{array}$ & $\begin{array}{l}188 \\
(36)\end{array}$ \\
\hline $\begin{array}{l}\text { Tresch } \\
\text { (Carroll Tr) }\end{array}$ & $8 / 20$ & 92 & 103 & 29 & 0.67 & $\begin{array}{l}15 \\
(6) \\
\end{array}$ & $\begin{array}{r}384 \\
(46) \\
\end{array}$ & $\begin{array}{r}399 \\
(46) \\
\end{array}$ & $\begin{array}{r}364 \\
(60) \\
\end{array}$ \\
\hline \multicolumn{10}{|c|}{ Brown trout 1998} \\
\hline Section & $\begin{array}{c}\text { Date } \\
\text { Marked }\end{array}$ & $\begin{array}{l}\text { Number } \\
\text { marked }\end{array}$ & $\begin{array}{l}\text { Number } \\
\text { captured }\end{array}$ & $\begin{array}{c}\text { Number } \\
\text { Recaptured }\end{array}$ & $\begin{array}{l}\text { Pooled } \\
\text { (P) }\end{array}$ & $\begin{array}{c}\text { Number } \\
\text { /mile } \\
6-10 \\
\text { inches }\end{array}$ & $\begin{array}{l}\text { Number } \\
\text { /mile } \\
>10 \text { inches }\end{array}$ & $\begin{array}{l}\text { Number } \\
\text { /mile } \\
>6 \text { inches }\end{array}$ & $\begin{array}{l}\text { Biomass/ } \\
\text { Mile (lbs.) }\end{array}$ \\
\hline Burleigh & $8 / 17$ & 48 & 39 & 9 & $\begin{array}{c}0.65 \\
\text { not } \\
\text { pooled }\end{array}$ & 0 & $\begin{array}{l}174 \\
(39)\end{array}$ & $\begin{array}{l}174 \\
(39)\end{array}$ & $\begin{array}{l}226 \\
(59)\end{array}$ \\
\hline $\begin{array}{l}\text { Brewery } \\
\text { Flats * }\end{array}$ & $8 / 20$ & 19 & 40 & 3 & - & - & - & - & - \\
\hline $\begin{array}{c}\text { Tresch } \\
\text { (Carroll Tr) }\end{array}$ & $8 / 19$ & 109 & 109 & 17 & 0.65 & $\begin{array}{r}123 \\
(14) \\
\end{array}$ & $\begin{array}{r}747 \\
(134) \\
\end{array}$ & $\begin{array}{r}870 \\
(137) \\
\end{array}$ & $\begin{array}{r}885 \\
(266) \\
\end{array}$ \\
\hline
\end{tabular}

*Too few recaptures for an estimate. 
numbers of rainbow and brown trout 10 inches or longer were similar to those seen in 1995 and 1996 (Table 2 and Hill et al. 1997). In 1998, numbers of rainbow at Burleigh and Brewery Flats 10 inches or longer were also similar to those seen in 1995-1997 (Table 2 and Hill et al. 1997). However, numbers of rainbow trout over 10 inches at Tresch (Old Carroll Trail) and numbers of brown trout over 10 inches in all sections were higher in 1998 than in 1996 and 1997. As is typical in Big Spring Creek, numbers of trout 10 inches and larger in the Brewery Flats and Burleigh sections were less than half those found below town in the Tresch Section.

In 1997, point estimates of rainbow trout less than 10 inches increased dramatically in both the Burleigh and Brewery Flats sections, but decreased in 1998 to near historical levels (Table 2 and Hill et al. 1997). Point estimates in the Burleigh section increased from 49 per mile in 1996 (Hill et al. 1997) to 1010 per mile in 1997. Point estimates in the Brewery Flats section increased from 208 to 733 per mile (Hill et al. 1997 and Table 2). However, the 1997 and 1998 estimates for 6-10 inch fish are highly suspect due to the low number of small fish captured and recaptured for this size group which resulted in a large standard deviation (SD) (Table 2). We also calculated age statistics for Big Spring Creek trout captured in 1997 and 1998 (Appendices Tables 1 and 2). Sixty rainbow trout and 17 brown trout from Big Spring Creek were sampled for whirling disease in 1997. Results were negative.

A thermograph placed in Big Spring Creek at the Burleigh Fishing Access Site (FAS) recorded water temperature from August 1997 to the end of June 1998. Stream temperature at that site never exceeded the lethal tolerance for trout. In fact, average daily temperature only reached the preferred temperature for trout $\left(55^{\circ} \mathrm{F}\right)$ during August 1997 and June 1998. The thermograph was not recording in July of either year (Figure 2).

Twelve substrate core samples were taken at each of three areas of Big Spring Creek in 1997. Sampling sites included the lower MFWP fish hatchery, Burleigh FAS and the Old Carroll Trail Fishing Access Site (FAS). Samples were taken in areas used by spawning rainbow trout. Both redds and undefined areas were sampled. Skewed results were obtained because samples were taken about 2 inches too deep, which increased the proportion of smaller sediment. Only one third of the samples indicated greater than $0 \%$ survival for rainbow embryos and only 4 of 36 samples had greater than $20 \%$ survival. All but one sample site with survival greater than $20 \%$ existed on a redd and all were located above Lewistown (Appendix Tables 3-5). Percent survival was compared using KruskalWallis one-way nonparametric analysis of variance. There was no difference in estimated rainbow embryo survival between the Lower Hatchery, Burleigh or Tresch sections of Big Spring Creek $(p=0.49)$. Survival values were significantly higher $(p=0.003)$ in redds than undefined areas.

Sediment samples were taken at three sites above Lewistown in 1997 and analyzed for hydrocarbons and PCB's (Table 3). Hydrocarbons were detectable at all three sites, but were not extremely high (Don Skaar, MFWP, personal communication). The only PCB 


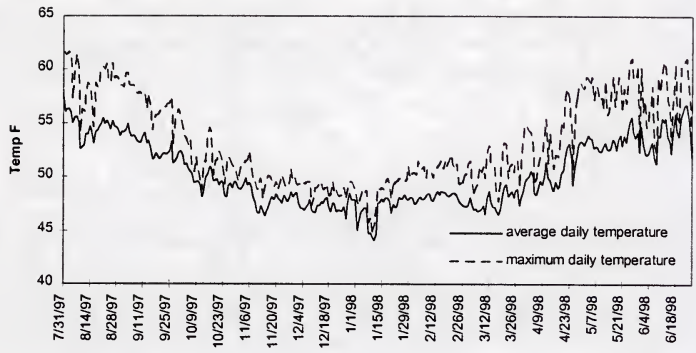

Figure 2. Stream temperature of Big Spring Creek at Burleigh Fishing Access Site, near Lewistown, Montana, August 1997-June 1998.

Table 3. Hydrocarbon and PCB concentrations obtained from sediment samples at three sites on Big Spring Creek, Montana in 1997.

\begin{tabular}{crccc}
\hline Sample site & $\begin{array}{c}\text { Diesel Range } \\
\text { Organics }\end{array}$ & $\begin{array}{c}\text { Total Extractable } \\
\text { Hydrocarbons (ppm) }\end{array}$ & $\begin{array}{c}\text { Aroclor } 1254 \\
\text { (ppb) }\end{array}$ \\
\hline Burleigh & 14 & 27 & $9.8^{2}$ \\
Brewery Flats & 17 & 41 & 162 \\
Garfield School & 23 & 54 & 53 \\
\hline
\end{tabular}

1 wet weight;

$\underline{2}$ below detection limit of $33 \mathrm{ppb}$.

found was Aroclor 1254; its concentration was variable (Table 3). At the most upstream sampling site (Burleigh FAS), wet weight of the Aroclor 1254 was 9.8 parts per billion (ppb), which was below the laboratories detection limits of $33 \mathrm{ppb}$. Two miles downstream, below the Brewery Flats FAS, Aroclor 1254 was $162 \mathrm{ppb}$. A 53 ppb wet weight of Aroclor 1254 was found near Garfield School in the mill ditch. The PCB value found at the Brewery Flats FAS may be enough to cause biological effects (Don Skaar, MFWP, personal communication). Additional PCB testing was done by a variety of parties in 1997 and 1998. Results indicate that the Brewery Flat Area is where the highest level of PCB's are located (Lewistown News-Argus 1998). MFWP conducted extensive soil tests throughout the Brewery Flats FAS and found the area to be virtually PCB free (Lewistown News-Argus 1998). 
Construction of a new meandering channel to replace 0.5 miles of straightened channel was started at Brewery Flats in 1998. Channel construction was halted due to a lack of gravel in the bottom of the new channel. Gravel will be imported and channel construction completed in 1999.

\section{Warm Springs Creek}

In 1997, Warm Spring Creek was electrofished for the first time since 1981. The sampled section was 9000 feet long and located approximately 10 miles downstream from Warm Spring. Species captured included rainbow trout, brown trout, smallmouth bass, stonecat, longnose sucker, white sucker, mottled sculpin, longnose dace, and shorthead redhorse. A northern pike was observed but not captured in the section. Summary statistics are shown in Table 4. A mark-recapture estimate found 165 rainbow trout greater than 9 inches long per mile (Table 5). Average total length of three year old and older rainbow trout was 12 inches (Table 6). The MFWP has long stocked this water with rainbow trout, due to warm spring's water temperature of $68^{\circ} \mathrm{F}$. However, dozens of rainbow trout from 2-6 inches were captured or seen during electrofishing. Based on 1996 and 1997 Big Spring Hatchery stocking records, these rainbow trout were from natural reproduction. To evaluate the necessity of stocking rainbow trout, in 1997 and 1998 the stocked rainbow trout were adipose clipped. Whirling disease analysis from 43 rainbow trout sampled found no infection.

The age and size structure of the smallmouth bass population indicates they are naturally reproducing. Only one rainbow trout tag was returned from 155 rainbow tagged in 1997. No tags have been returned from the 6 brown trout or 3 smallmouth bass tagged in 1997 . In December 1998, a shorter section was electrofished within the section electrofished in 1997 (Table 4). No brown trout or northern pike were captured in that effort, but spawning rainbow trout and smallmouth bass too small to have been stocked were captured. No adipose clipped rainbow trout or any tagged fish were captured during 1998 sampling. One 7.9 inch mountain sucker was captured during 1998 sampling. A thermograph was placed in Warm Springs Creek in December 1997, which recorded through mid-October 1998. Maximum daily temperature at the state bridge exceeded $75{ }^{\circ} \mathrm{F}$ for most of July and August, which would be lethal to any trout without access to cooler refugia. Good spawning temperature for rainbow trout $\left(50^{\circ} \mathrm{F}\right.$ to $60^{\circ} \mathrm{F}$ ) occurred from mid December (when the thermograph began recording) through late March 1998 (Figure 3).

\section{Other Streams}

Lost Creek - This water contains the only known pure westslope cutthroat trout population in the Otter Creek drainage. The westslope cutthroat habitat is separated and protected from a brook trout population downstream by a 10 -foot barrier falls. Another falls farther upstream also acts as a barrier and has resulted in about 0.5 miles of fishless water. On September 11, 1997, 60 westslope cutthroat trout varying in size from 4-10 inches long 
Table 4. Fish statistics for streams sampled in the Lewistown area of Central Montana in 1997 and 1998.

\begin{tabular}{|c|c|c|c|c|c|c|}
\hline $\begin{array}{c}\text { Stream } \\
\text { (legal description) }\end{array}$ & Date & $\begin{array}{c}\text { Section } \\
\text { length }(\mathrm{ft})^{l}\end{array}$ & $\begin{array}{l}\text { Temp } \\
{ }^{\circ} \mathrm{F}\end{array}$ & Species: & $\begin{array}{l}\text { Number } \\
\text { Captured }\end{array}$ & $\frac{\text { Length (in) }}{\text { Mean (Range) }}$ \\
\hline Warm Springs Creek & $5 / 7 / 97$ & 9000 & 65 & Rainbow trout & 296 & $8.6(2.8-14.2)$ \\
\hline \multirow[t]{7}{*}{ (T17NR17ES7) } & $6 / 4 / 97$ & & & Smallmouth bass & 46 & $6.7(3.3-13.9)$ \\
\hline & & & & Brown trout & 8 & $16.7(14.6-19.1)$ \\
\hline & & & & Stonecat ${ }^{3}$ & 6 & $7.3(6.6-7.6)$ \\
\hline & & & & Longnose sucker ${ }^{3}$ & 10 & $8.7(4.2-17.2)$ \\
\hline & & & & White sucker ${ }^{3}$ & 31 & $11.1(3.2-14.5)$ \\
\hline & & & & Longnose dace ${ }^{3}$ & 7 & $3.7(2.3-4.7)$ \\
\hline & & & & $\mathrm{SHRH}^{3}$ & 9 & $14.2(2.6-19.0)$ \\
\hline \multirow{9}{*}{$\begin{array}{l}\text { Warm Springs Creek } \\
\text { (T17NR17ES7) }\end{array}$} & $12 / 17 / 98$ & 8000 & 57 & Rainbow trout & 95 & $9.1(5.3-25.8)$ \\
\hline & & & & Smallmouth bass & 19 & $7.9(2.1-14.6)$ \\
\hline & & & & Stonecat & 15 & $6.7(4.0-8.0)$ \\
\hline & & & & Longnose sucker & 33 & $10.3(6.5-15.1)$ \\
\hline & & & & White sucker & 53 & $11.1(6.4-15.1)$ \\
\hline & & & & Mountain sucker & 1 & $7.9 \quad-$ \\
\hline & & & & Longnose dace & 4 & $4.1(3.7-4.5)$ \\
\hline & & & & Carp ${ }^{4}$ & 2 & $8.0(7.2-8.8)$ \\
\hline & & & & SHRH & 7 & $11.8(6.1-18.7)$ \\
\hline \multirow{5}{*}{$\begin{array}{l}\text { S. F. Flatwillow } \mathrm{Cr} \\
\text { (T12NR21ES11) }\end{array}$} & $9 / 2 / 97$ & 600 & 54 & Brook Trout & 35 & $3.9(2.5-9.4)$ \\
\hline & & & & White sucker & 5 & $7.9(2.5-15.2)$ \\
\hline & & & & Longnose sucker & 53 & $4.0(2.8-12.1)$ \\
\hline & & & & Longnose dace & 1 & 3.1 \\
\hline & & & & Lake chub & 3 & $3.3(3.1-3.6)$ \\
\hline \multirow{4}{*}{$\begin{array}{l}\text { S. F. Judith River } \\
\text { (T12NR11ES23) }\end{array}$} & $8 / 12 / 97$ & 600 & 58 & Rainbow trout & 40 & $7.1(4.2-12.5)$ \\
\hline & & & & Brook trout & 1 & 5.0 \\
\hline & & & & $\mathrm{RBxCT}$ & 4 & $6.8(6.2-8.6)$ \\
\hline & & & & Mountain whitefish & 13 & $8.5(4.1-11.3)$ \\
\hline \multirow{6}{*}{$\begin{array}{l}\text { Beaver Creek } \\
\text { (T14NR17ES36) }\end{array}$} & $6 / 30 / 98$ & 600 & 56 & Brook trout & 13 & $2.5-12.0(6.8)$ \\
\hline & & & & Longnose sucker & 14 & $5.1-14.2(10.4)$ \\
\hline & & & & White sucker & 1 & 9.8 \\
\hline & & & & Longnose dace & 6 & $2.1-4.0(3.4)$ \\
\hline & & & & Lake chub & 2 & $3.9-4.7(4.3)$ \\
\hline & & & & Sculpin & 5 & $2.5-3.9(3.0)$ \\
\hline \multirow{4}{*}{$\begin{array}{l}\text { Flatwillow Creek } \\
\text { (T12NR23ES5,8) }\end{array}$} & $5 / 26 / 98$ & 3500 & 68 & Brown trout & 31 & $4.8-17.1(13.3)$ \\
\hline & & & & White sucker & 221 & $3.2-18.1(8.7)$ \\
\hline & & & & Longnose sucker & 47 & $3.3-15.9(9.3)$ \\
\hline & & & & Longnose dace ${ }^{3}$ & 76 & $1.7-4.3(2.6)$ \\
\hline
\end{tabular}

1 section length estimated in field and measured on maps; 2 SHRH = shorthead redhorse; RBxCT = rainbow/cutthroat trout hybrid; 3 small subsample of this species was measured; 4 about 1016 "-22" Carp were observed but not netted. 
Table 5. Mark recapture statistics from population estimates done in 1997 on Warm Springs Creek, Montana. (SD in parenthesis).

\begin{tabular}{|c|c|c|c|c|c|c|c|c|}
\hline \multicolumn{9}{|c|}{ Rainbow trout } \\
\hline $\begin{array}{c}\text { Date } \\
\text { Marked }\end{array}$ & $\begin{array}{l}\text { Number } \\
\text { Marked }\end{array}$ & $\begin{array}{l}\text { Number } \\
\text { captured }\end{array}$ & $\begin{array}{c}\text { Number } \\
\text { Recaptured }\end{array}$ & $\begin{array}{l}\text { Pooled } \\
\text { (P) }\end{array}$ & $\begin{array}{l}\text { Number/mile } \\
9-10 \text { inches }\end{array}$ & $\begin{array}{c}\text { Number/mile } \\
>10 \text { inches }\end{array}$ & $\begin{array}{c}\text { Number/mile } \\
>9 \text { inches }\end{array}$ & $\begin{array}{c}\text { Biomass/ } \\
\text { Mile } \\
\text { (lbs.) }\end{array}$ \\
\hline $5 / 7$ & 128 & 69 & 31 & 0.66 & $17(5)$ & $148(18)$ & $165(18)$ & $95(13)$ \\
\hline
\end{tabular}

Table 6. Number of rainbow trout greater than 9 inches at age from 1997 estimate done on Warm Springs Creek, Montana.

\begin{tabular}{cccc}
\hline & \multicolumn{3}{c}{ Age of rainbow trout } \\
\cline { 2 - 4 } & $2(2)$ & $73(14)$ & 3 \& older \\
\hline $\begin{array}{c}\text { Number/mile (SD) } \\
\text { Average total } \\
\text { length } \\
\text { (inches) }\end{array}$ & 9.4 & 10.8 & $90(16)$ \\
\hline
\end{tabular}

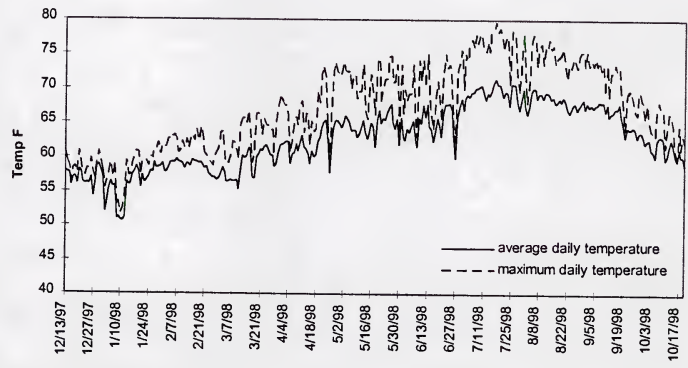

Figure 3. Stream temperature of Warm Springs Creek at the state bridge near Lewsitown, Montana, December 1997-October 1998. 
were moved above the second barrier falls. This transfer approximately doubled the occupied westslope cutthroat trout habitat. Additional westslope cutthroat trout were transferred in 1998 (Mike Enk, personal communication). This range extension was a cooperative effort between the United States Forest Service (USFS) and MFWP and required genetic and disease testing of the westslope cutthroat trout as well as surveys of aquatic invertebrates and amphibians.

South Fork Judith River - In August 1997, a two-pass electrofishing estimate was made on the Indian Water Gap section of the South Fork Judith River. Data is summarized in Tables 4 and 7. A very similar section was shocked in 1987 and 1994. In 1997, the flow was much higher and a slightly longer section was electrofished. Species diversity was similar to past years with numerous rainbow trout and mountain whitefish but only a single brook trout (Table 4). Rainbow trout numbers increased from earlier years. In 1997, rainbow trout longer than 4 inches were estimated with $95 \%$ Confidence Intervals $(\mathrm{Cl})$ at $80( \pm 6)$ per 1000 feet compared with $55( \pm 3$ ) in 1994 and 63( \pm 2 ) in 1987 (Tews et al. 1995, MDFWP 1989). Point estimates of mountain whitefish longer than 4 inches varied from 22 26 with 95\% confidence intervals overlapping for each estimate. Stocking of catchable rainbow trout ended in 1994.

South Fork Flatwillow Creek - This water was electrofished on September 2, 1997. One pass sampling of a 600 -foot section found 35 brook trout (Table 4). All but two of these fish were less than 5 inches in total length. Small longnose suckers were abundant. White suckers, longnose dace and lake chub were also sampled. Anglers report that brook trout numbers have declined dramatically in the last 2-3 years and data collected by MFWP in 1974 (Poore 1975) also indicates numbers of brook trout larger than 5 inches have declined.

Beaver Creek - This stream was electrofished in cooperation with Natural Resource Conservation Service personnel on June 30,1998 at Regli's Ranch where the stream was restored in 1997. A diverse fish community was captured including brook trout, lake chub, longnose dace, sculpin, longnose sucker and white sucker. Brook trout ranged from 2.512.0 inches in length (Table 4).

Flatwillow Creek - This stream was electrofished below the Lucky Fork Bridge on May 26 , 1998. There was a lot of beaver activity in the area and the water was too deep in many places to safely complete a mark-recapture estimate of abundance. In one pass, brown trout, white sucker, longnose sucker, longnose dace, lake chub and sculpins were captured. Although lake chub and sculpins were sampled, the limitations of the sampling equipment prevented an accurate determination of these species relative abundance. Thirty-one brown trout were captured ranging from 4.8-17.1 inches in length. White suckers were the most numerous fish species (Table 4). 
Table 7. Population estimates from South Fork Judith River, Montana on August 12 , 1997 for fish greater than 4 inches in total length.

\begin{tabular}{ccc}
\hline Species & $\begin{array}{c}\text { Number per 1000 feet } \\
(95 \% \text { Confidence Interval })\end{array}$ & $\begin{array}{c}\text { Probability of } \\
\text { Capture }\end{array}$ \\
\hline Rainbow trout & $80( \pm 6)$ & 0.79 \\
Mountain whitefish & $22( \pm 2)$ & 0.81 \\
\hline
\end{tabular}

Dry Wolf Creek - In a cooperative effort with the USFS, a two pass depletion estimate was completed on Dry Wolf Creek, 0.5 miles above the campground. Rainbow trout stocking was discontinued in 1995 to protect the westslope cutthroat trout population and no rainbow trout were captured in this electrofishing effort on September 11, 1998. Twenty-eight westslope cutthroat trout were captured, which ranged from 2.6-12.0 inches in total length. Twenty-four brook trout were captured, which ranged in length from 2.2-9.6 inches in total length. Number estimates were considerably higher than in 1994 when the same area was surveyed. In 1994, westslope cutthroat trout were estimated at 11 per 1000 feet (Tews et al. 1995), while we estimated 58 per 1000 feet in 1998. Brook trout were estimated at 10 per 1000 feet in 1994 (Tews et al. 1995), and at 49 per 1000 feet in 1998 . However, fish biomass in the stream is probably similar to 1994 , because the stocked 11-13 inch rainbow trout found in 1994 are no longer present.

Cottonwood Creek (Highwoods) - Brook trout removal was conducted in cooperation with the USFS on Cottonwood Creek on September 22, 1998. Brook trout were removed to protect westslope cutthroat trout in preparation for installation of a fish passage barrier in 1999. Brook trout were removed from the barrier site upstream to where the stream is subterranean. A total of 494 brook trout were removed, 45 of which were from a small tributary. In the 0.25 miles of stream sampled, 129 westslope cutthroat trout were captured, which ranged from 2.0 inches to 10.8 inches.

Brief spot electrofishing surveys were done on two other streams in 1997. Brook trout were found in McCartney Creek (T13NR20ES24), a tributary of Flatwillow Creek, which originates from a $10-20 \mathrm{cfs}$ spring. We sampled about 2 miles below the spring. Smith Creek (T11NR11ES6), a tributary to the South Fork of the Judith River was sampled for westslope cutthroat trout. The only fish sampled were visually identified as rainbow trout and obvious rainbow $x$ cutthroat trout hybrids. 
Great Falls Area

\section{Smith River}

We obtained population estimates during fall 1998 for both rainbow and brown trout from the Eagle Creek and the Deep Creek sections. Data will be presented in the a future report.

\section{Missouri River}

We also obtained population estimates for brown trout during spring 1998 and for both rainbow and brown trout during fall 1998 in the Craig and Cascade sections. Data will be presented in a future report.

\section{Habitat Protection}

Providing input and recommendations about alterations of streambeds or banks by private individuals or government entities are handled through a permit process. The 1975 Natural Streambed and Land Preservation Act (310) involves the private sector while the Stream Protection Act of 1963 (SPA) covers government agencies. A total of 49 stream protection projects were reviewed and processed in the Choteau area. Fortyone of these involved the 310 law and the remaining 8 projects involve the 124 law. In the Lewistown area 20 Natural Streambed and Land Preservation Act " 310 " and 11 "124" permits were processed during the report period. Also, an additional 86 " 310 's" and 18 "124" permits were processed through the Great Falls office over the entire 1998 calendar year. This resulted in a total of 147 " 310 's" and 37 "124" permits. Site inspections were made on most of the projects. No significant water discharge permit applications or renewals were received and no significant pollution complaints were received during the report period.

\section{DISCUSSION AND RECOMMENDATIONS}

Cutthroat trout populations should continue to be investigated and tested for genetic purity as westslope cutthroat trout. Where possible, we will coordinate investigations with the US Forest Service. It is recommended to transfer additional westslope cutthroat from the Middle Fork Dupuyer Creek to the South Fork Dupuyer Creek. Additional streams should also be selected for similar transfers. In 1999, it is recommended to investigate species composition and determine trout population numbers in the forks of the Sun River. 
We recommend continuing with the stocking plan for the Tiber Section area of the Marias River using both brown and rainbow trout fingerlings through 2002 or for four more years. The intended results are to increase brown trout numbers, maintain a two species fishery and provide a forage fish (rainbow trout) for the brown trout. Trout population trends will continue to be monitored on a biannual basis with the next survey scheduled in 2000 . Special attention will be directed at evaluating the success of brown and rainbow trout fingerling plants and the extent of natural reproduction in the Tiber Section. We will continue to develop management recommendations which could include changes in Tiber Dam operations or habitat improvements) to address limiting factors and enhance the trout population.

Population monitoring on Big Spring Creek should continue for evaluation of the Brewery Flats Project as well for monitoring general population trends. Rainbow trout recruitment needs to be evaluated in Big Spring Creek, as there have been very low numbers of small rainbow in the Burleigh Section for several years. Sediment cores found substrate to be very silty and equations predicted 0 survival at many sites. However, silty substrate on redds may not be preventing recruitment, since embryo survival estimates were poor for all sections of stream, even where recruitment is excellent in the Tresch section. One-pass electrofishing surveys should continue to be done on Warm Springs Creek to determine numbers of hatchery stocked rainbow and to document how far upstream natural reproduction is occurring. Hatchery rainbow stocked in Warm Spring Creek should continue to be adipose clipped.

Monitoring of the Eagle and Deep Creek sections on the Smith River will continue. We will also continue to electrofish two sections on the Missouri River to obtain population estimates. Additional monitoring on the Missouri River and it tributaries, especially Little Prickley Pear Creek, will be continued to document any impacts from the presence of Myxobolus cerebralis.

Stream protection/preservation activities will continue to be processed as projects occur.

\section{ACKNOWLEDGMENTS}

The authors acknowledge the following individuals for assistance in collecting, assembling and analyzing field data and other information for this project: Paul Hamlin, Kelly Smith, Maurice Frey, Mike Barrick, Jimmy Forrest, Randy Berry, Rick Bryant, Bob Dafoe (rancher), Tom Flowers, Noelle Guerrie, Naohisa Kanda, Steve Leathe, Ray Paige, Bob Peebles (Boone \& Crockett Ranch manager), Randy Rodencal, Tom Salansky (rancher), Kenny Staigmiller and Matt Stevens. Dr. Robb Leary from the University of Montana Genetics Lab conducted the laboratory testing to determine the genetic purity of westslope cutthroat trout. 


\section{REFERENCES CITED}

Enk, Michael. 1998. U.S. Forest Service, Lewis and Clark Forest Fisheries Biologist, Great Falls MT. Personal communications.

Gardner, W.M. and R. K. Berg. 1983. Instream flow requirements for the Marias River fishery downstream of Tiber Dam. Mont. Dept. Fish, Wildlife \& Parks. Helena. 82 pp.

Gardner, W. M. 1988. Northcentral Montana Fisheries Study, Middle Missouri River Basin - instream flow studies. Mont. Dept. Fish Wildlife and Parks, Helena. Fed. Aid to Fish and Wildlife Rest. Proj. F-38-R-3, Study No. II, Job B. 20 pp.

Hill, W. J., G. A. Liknes, and A. E. Tews. 1997. Statewide fisheries investigation. Northcentral Montana coldwater streams. Project F-78-R-3. Job Progress Report. Montana Department of Fish, Wildlife \& Parks. Fisheries Division. Helena, Montana.

Hill, W. J., G. A. Liknes, and A. E. Tews. 1998. Statewide fisheries investigation. Northcentral Montana coldwater stream ecosystems. 1997 Annual Report. Project F-78-R-4. Job Progress Report. Montana Department of Fish, Wildlife \& Parks. Fisheries Division. Helena, Montana.

Hill W. J. 1998. Environmental assessment of westslope cutthroat trout introduction into South Fork Dupuyer Creek, Pondera County, Montana. Montana Fish, Wildlife \& Parks. Fisheries Division, Helena, Montana.

Irving, J. S. and T. C. Bjornn. 1984. Effects of substrate size composition on survival of kokanee salmon and cutthroat and rainbow trout embryos. Technical Report 84-6. Idaho Cooperative Fishery Research Unit, University of Idaho Moscow. Submitted to the Intermountain Forest and Range Experiment Station, Boise, Idaho.

Leathe, S. A. 1983. A cost-effective electrofishing technique to determine fish population size in small headwater streams in Montana. FWP.

Lewistown News-Argus, 1998. December 9, 1998 page 3. Lewistown, MT.

Mavrakis, P. H. and Dan L. Yule. 1998. North Platte comprehensive fisheries study: Creel survey and stocking evaluation, 1995-1996. Wyoming Game and Fish Dept. Cheyenne. 
Montana Department of Fish, Wildlife and Parks. 1989. Application for reservations of water in the Missouri River Basin above Fort Peck Dam. Montana Fish, Wildlife and Parks. Helena, Montana.

Montana Department of Fish, Wildlife and Parks. 1994. MarkRecapture Version 4.0. A software package for fishery population estimates. Montana Department of Fish, Wildlife and Parks. Helena, Montana.

Novotny, D. W. and G. R. Priegal. 1974. Electrofishing boats-improved designs and operational guidelines to increase the effectiveness of boom shockers. Wisc. Dept. Nat. Resc. Tech. Bull. No. 73. 48 pp.

Poore, Michael. 1975. Central Montana Fisheries Study. Inventory of Waters in the Eastern Half of Region Four. Project F-5-R-24. Job I-b. Montana Department of Fish and Game, Fisheries Division. Job Progress Report.

Ricker, W. E. 1975. Computation and interpretation of biological statistics of fish populations. Fisheries Research Board of Canada Bulletin 191.

Shepard B. B. and P. J. Graham. 1982. Monitoring and spawning bed material used by bull trout on the Glacier View district, Flathead National Forest. Completion Report. Montana Department of Fish, Wildlife and Parks. Region 1, Kalispell, Montana.

Skaar, Don. Montana Department of Fish, Wildlife and Parks, Water Pollution Biologist, Helena, MT. Personal Communications.

Tews, A. E., W. M. Gardner, G. A. Liknes and W. J. Hill. 1995. Statewide Fisheries Investigations. Northcentral Montana Coldwater Streams. F-78-R-1. Montana Department of Fish, Wildlife and Parks. Fisheries Division. Job Progress Report. Helena, Montana.

Prepared by: Anne E. Tews. William M. Gardner, William J. Hill, George A. Liknes and Emily C. Zollweg.

Date: Date: December. 1999

Principal Fish Species Involved: Rainbow trout, cutthroat trout, westslope cutthroat trout, brown trout, brook trout, arctic grayling, mountain whitefish, mottled sculpin, smallmouth bass, longnose sucker, white sucker, longnose dace, shorthead redhorse and stonecat. 
Code Numbers of Waters Referred to in Report:

$\begin{array}{ll}14-1080 & \text { Cut Bank Creek } \\ 14-3240 & \text { Marias River } \\ 14-3480 & \text { M. Fk. Dupuyer Creek } \\ 14-4000 & \text { N. Fk. Teton River } \\ 14-4680 & \text { Rival Creek } \\ 14-5480 & \text { S. Fk. Dupuyer Creek } \\ 15-3360 & \text { Sage Creek } \\ 16-0200 & \text { Beaver Creek } \\ 16-0310 & \text { Big Spring Creek, Sec 2 } \\ 16-0760 & \text { Cottonwood Creek (Highwoods) } \\ 16-1280 & \text { Dry Wolf Creek } \\ 16-3480 & \text { Smith Creek } \\ 16-3520 & \text { South Fork Judith } \\ 16-3920 & \text { Warm Springs Creek } \\ 17-4374 & \text { Lost Creek } \\ 17-4896 & \text { Missouri River Section 09 } \\ 17-6832 & \text { Smith River Section 02 } \\ 18-2640 & \text { Flatwillow Creek } \\ 18-3750 & \text { McCartney Creek } \\ 18-5610 & \text { S. Fk. Flatwillow Creek } \\ 20-0600 & \text { Big George Gulch } \\ 20-2350 & \text { Gates Creek } \\ 20-3200 & \text { Lange Creek } \\ 20-4400 & \text { N. Fk. Sun River } \\ 20-5600 & \text { S. FK. Sun River } \\ 20-6110 & \text { Sunny Slope Canal } \\ 20-6750 & \text { Wrong Creek } \\ 20-8400 & \text { Tunnel Lake } \\ & \end{array}$


Appendix Table 1. Age statistics from Big Spring Creek, Montana for 1997.

\begin{tabular}{|c|c|c|c|}
\hline \multicolumn{4}{|c|}{ Burleigh section - Rainbow trout } \\
\hline & I & II & IIIt \\
\hline Number/mile (SD) & $930(698)$ & $324(121)$ & $129(31)$ \\
\hline Average TL (in) & 7.2 & 11.2 & 13.4 \\
\hline \multicolumn{4}{|c|}{ Burleigh section - Brown trout } \\
\hline & I & II & IIIt \\
\hline Number/mile(SD) & 0 & $12(7)$ & 120 (19) \\
\hline Average TL (in) & - & 12.6 & 15.3 \\
\hline
\end{tabular}

\begin{tabular}{|c|c|c|c|}
\hline \multicolumn{4}{|c|}{ Brewery Flats section - Rainbow trout } \\
\hline & I & II & IIIt \\
\hline Number/mile (SD) & $624 \quad(235)$ & $214 \quad(44)$ & $163 \quad(26)$ \\
\hline Average TL (in) & 7.3 & 9.8 & 12.3 \\
\hline
\end{tabular}

\begin{tabular}{|c|c|c|c|}
\hline \multicolumn{4}{|c|}{ Brewery Flats section - Brown trout } \\
\hline & I & II & IIIt \\
\hline Number/mile (SD) & 0 & $42(9)$ & $145(18)$ \\
\hline Average TL (in) & - & 13.1 & 14.6 \\
\hline
\end{tabular}

\begin{tabular}{|c|c|c|c|}
\hline \multicolumn{4}{|c|}{ Tresch section - Rainbow trout } \\
\hline & I & II & IIIt \\
\hline Number/mile (SD) & $900(87)$ & $509(43)$ & $387(43)$ \\
\hline Average TL (in) & 7.5 & 11.8 & 14.0 \\
\hline
\end{tabular}

\begin{tabular}{ccccc}
\hline & \multicolumn{4}{c}{ Tresch section - Brown trout } \\
\cline { 2 - 5 } & \multicolumn{1}{c}{ I } & I I & II + \\
\hline Number/mile (SD) & $48(14)$ & $154(29)$ & $197(34)$ \\
Average TL & 11.0 & 12.7 & 14.6 \\
\hline
\end{tabular}


Appendix Table 2. Age statistics from Big Spring Creek, Montana for 1998.

\begin{tabular}{|c|c|c|c|}
\hline \multicolumn{4}{|c|}{ Burleigh section - Rainbow trout } \\
\hline & I & II & IIIt \\
\hline Number/mile (SD) & $144(34)$ & 82 (15) & $131(22)$ \\
\hline Average TL (in) & 7.9 & 11.3 & 13.6 \\
\hline
\end{tabular}

\begin{tabular}{lcccc}
\hline \multicolumn{4}{c}{ Burleigh section -Brown trout } \\
\hline & I & II & I I + \\
\hline Number/mile (SD) & $12(15)$ & $5(5)$ & $169(38)$ \\
Average TL (in) & 8.9 & 11.5 & 15.7 \\
\hline
\end{tabular}

\begin{tabular}{|c|c|c|c|}
\hline \multicolumn{4}{|c|}{ Brewery Flats section - Rainbow trout } \\
\hline & I & II & IIIt \\
\hline Number/mile (SD) & $429(94)$ & $91(17)$ & $134(17)$ \\
\hline Average TL (in) & 7.7 & 10.8 & 12.3 \\
\hline
\end{tabular}

\begin{tabular}{lcccc}
\hline \multicolumn{5}{c}{ Tresch section - Rainbow trout } \\
\hline & I & I I & I I + \\
\hline Number/mile (SD) & 1004 (91) & $593(69)$ & $1127(68)$ \\
Average TL (in) & 8.0 & 10.5 & 13.2 \\
\hline
\end{tabular}

\begin{tabular}{ccccc}
\hline & \multicolumn{3}{c}{ Tresch section - Brown trout } \\
& I & II & III+ \\
\hline Number/mile (SD) & $98(23)$ & $240(42)$ & $532(132)$ \\
Average TL & 9.3 & 12.0 & 15.6 \\
\hline
\end{tabular}


Appendix Table 3. Percent sediment remaining in sieve for each sample site and equation values calculated to determine percent rainbow survival from sediment cores take from near the Lower State Fish Hatchery on Big Spring, Creek, Montana in 1997. $\mathrm{U}=$ undefined sample site and $\mathrm{R}=$ redd sampled.

\begin{tabular}{|c|c|c|c|c|c|c|c|c|c|c|c|c|}
\hline \multicolumn{13}{|c|}{ Lower Hatchery sample sites } \\
\hline Sieve & Al & A2 & A3 & A4 & A5 & A6 & B1 & B2 & B3 & B4 & B5 & $\mathrm{B} 6$ \\
\hline Size $(\mathrm{cm})$ & $\mathrm{U}$ & $\mathrm{R}$ & $\mathrm{R}$ & $\mathrm{U}$ & $\mathrm{U}$ & $\mathbf{R}$ & $\mathrm{U}$ & $\mathrm{U}$ & $\mathrm{U}$ & $\mathrm{U}$ & $\mathrm{U}$ & $\mathrm{R}$ \\
\hline 50.8 & 0 & 0 & 3.13 & 0 & 2.09 & 6.10 & 2.10 & 8.40 & 0 & 5.19 & 0 & 15.65 \\
\hline 25.4 & 10.47 & 25.75 & 29.21 & 8.13 & 16.77 & 21.79 & 11.67 & 13.16 & 19.6 & 17.03 & 11.54 & 11.41 \\
\hline 12.4 & 20.60 & 29.14 & 21.03 & 29.16 & 25.98 & 18.53 & 24.55 & 17.70 & 20.37 & 20.95 & 27.88 & 21.50 \\
\hline 6.3 & 15.81 & 15.12 & 16.09 & 18.00 & 12.64 & 8.35 & 17.08 & 13.42 & 10.42 & 14.08 & 17 & 13.25 \\
\hline 4.76 & 4.89 & 4.39 & 4.36 & 4.46 & 4.62 & 2.42 & 4.44 & 4.61 & 4.51 & 4.69 & 5.22 & 4.42 \\
\hline 2.36 & 9.75 & 9.73 & 9.13 & 9.60 & 9.38 & 4.22 & 9.65 & 9.33 & 12.24 & 9.20 & 9.55 & 9.26 \\
\hline 0.85 & 8.23 & 7.71 & 7.58 & 7.82 & 7.86 & 6.08 & 9.72 & 13.54 & 12.08 & 8.29 & 10.06 & 10.60 \\
\hline 0.74 & 27.07 & 6.27 & 6.92 & 20.17 & 15.43 & 24.80 & 18.95 & 17.99 & 19.19 & 19.08 & 17.22 & 12.52 \\
\hline$<0.74$ & 3.18 & 1.89 & 2.55 & 2.66 & 5.23 & 7.71 & 1.82 & 1.84 & 1.57 & 1.49 & 1.51 & 1.40 \\
\hline R2 & .958 & .925 & .943 & .917 & .934 & .962 & .962 & .993 & .990 & .976 & .941 & .975 \\
\hline$\%<8.5$ & 30 & 8 & 9 & 23 & 21 & 32 & 21 & 20 & 21 & 21 & 19 & 14 \\
\hline$\%<9.5$ & 68 & 42 & 41 & 64 & 54 & 55 & 60 & 58 & 59 & 55 & 60 & 48 \\
\hline P50 & 3.7 & 15.2 & 17.0 & 4.7 & 7.1 & 6.4 & 5.6 & 6.2 & 5.7 & 7.2 & 5.7 & 10.7 \\
\hline $\begin{array}{c}\% \mathrm{RB} \\
\text { survival }\end{array}$ & 0 & 34 & 29 & 0 & 0 & 0 & 0 & 0 & 0 & 0 & 0 & 5 \\
\hline
\end{tabular}


Appendix Table 4. Percent sediment remaining in sieve for each sample site and equation values calculated to determine percent rainbow survival from sediment cores take from the Burleigh FAS on Big Spring Creek, Montana in 1997. $U=$ undefined sample site and $R=$ redd sampled.

\begin{tabular}{llllllllllllll}
\hline \multicolumn{1}{c}{ Sieve } & $\mathrm{C1}$ & $\mathrm{C} 2$ & $\mathrm{C} 3$ & $\mathrm{C} 4$ & $\mathrm{D} 1$ & $\mathrm{D} 2$ & $\mathrm{D} 3$ & $\mathrm{D} 4$ & $\mathrm{E} 1$ & $\mathrm{E} 2$ & $\mathrm{E} 3$ & $\mathrm{E} 4$ \\
$\begin{array}{l}\text { Size } \\
\text { (cm) }\end{array}$ & $\mathrm{R}$ & $\mathrm{U}$ & $\mathrm{U}$ & $\mathrm{U}$ & $\mathrm{R}$ & $\mathrm{U}$ & $\mathrm{U}$ & $\mathrm{U}$ & $\mathrm{U}$ & $\mathrm{R}$ & $\mathrm{U}$ & $\mathrm{U}$ \\
\hline 50.8 & 2.60 & 0 & 0 & 0 & 9.77 & 6.31 & 7.34 & 0 & 0 & 20.96 & 23.4 & 17.49 \\
25.4 & 9.32 & 4.14 & 10.70 & 17.27 & 22.30 & 12.66 & 14.49 & 22.11 & 20.59 & 11.40 & 12.8 & 22.18 \\
12.4 & 29.54 & 28.07 & 30.65 & 37.49 & 21.53 & 23.12 & 18.04 & 27.49 & 19.50 & 16.03 & 15.62 & 16.31 \\
6.3 & 17.39 & 22.59 & 18.60 & 13.17 & 14.07 & 14.19 & 13.82 & 11.36 & 8.91 & 10.96 & 10.81 & 12.63 \\
4.76 & 4.91 & 6.82 & 6.32 & 2.95 & 5.39 & 5.61 & 5.91 & 2.85 & 3.74 & 4.85 & 4.04 & 4.88 \\
2.36 & 8.06 & 12.04 & 10.06 & 3.90 & 10.70 & 12.10 & 13.15 & 6.92 & 9.38 & 11.14 & 9.80 & 10.50 \\
0.85 & 6.78 & 5.50 & 5.80 & 1.78 & 8.02 & 11.29 & 10.83 & 7.02 & 12.36 & 10.33 & 8.73 & 7.25 \\
0.74 & 19.70 & 19.26 & 15.42 & 18.68 & 7.42 & 13.79 & 15.09 & 21.21 & 22.74 & 9.85 & 13.52 & 7.95 \\
$<0.74$ & 1.70 & 1.57 & 2.42 & 4.75 & 0.80 & 0.92 & 1.32 & 1.04 & 2.77 & 4.48 & 1.29 & 0.81 \\
& & & & & & & & & & & & \\
R2 & .982 & .972 & .980 & .954 & .979 & .986 & .995 & .957 & .986 & .980 & .993 & .992 \\
$\%<8.5$ & 21 & 21 & 18 & 23 & 8 & 15 & 16 & 22 & 25 & 14 & 15 & 9 \\
$\%<9.5$ & 50.5 & 56 & 48 & 39 & 42 & 56 & 56 & 53 & 48 & 48 & 46 & 39 \\
P50 & 9.1 & 6.8 & 10.4 & 26.1 & 15.0 & 7.1 & 6.9 & 8.1 & 5.1 & 10.9 & 12.1 & 18.3 \\
& & & & & & & & & & & & \\
\% RB & 2 & 0 & 0 & 0 & 34 & 0 & 0 & 0 & 0 & 5 & 4 & 30 \\
survival & & & & & & & & & & & & \\
\hline & & & & & & & & & & & &
\end{tabular}


Appendix Table 5. Percent sediment remaining in sieve for each sample site and equation values calculated to determine percent rainbow survival from sediment cores take from near the Lower State Fish Hatchery on Big Spring Creek, Montana in 1997. $U=$ undefined sample site and $R=$ redd sampled.

\begin{tabular}{|c|c|c|c|c|c|c|c|c|c|c|c|c|}
\hline \multicolumn{13}{|c|}{ Old Carroll Trail (Tresch) } \\
\hline Sieve & F1 & F2 & F3 & F4 & F5 & F6 & F7 & F8 & F9 & F10 & F11 & F12 \\
\hline Size $(\mathrm{cm})$ & $\mathrm{U}$ & $\mathrm{U}$ & $\mathrm{U}$ & $\mathrm{U}$ & $\mathrm{U}$ & $\mathrm{R}$ & $\mathrm{U}$ & $\mathrm{U}$ & $\mathrm{R}$ & $\mathrm{R}$ & $\mathrm{U}$ & $\mathrm{R}$ \\
\hline 50.8 & 5.66 & 14.05 & 4.05 & 5.41 & 0 & 0 & 4.78 & 0 & 0 & 0 & 13.59 & 0 \\
\hline 25.4 & 11.12 & 14.57 & 19.84 & 20.53 & 7.48 & 10.51 & 25.64 & 23.82 & 13.70 & 21.26 & 21.73 & 25.50 \\
\hline 12.4 & 24.22 & 17.43 & 16.48 & 25.19 & 17.74 & 20.79 & 21.51 & 24 & 17.38 & 21.85 & 18.79 & 25.19 \\
\hline 6.3 & 14.45 & 12.41 & 14.14 & 17.16 & 18.46 & 18.30 & 12.66 & 12.45 & 16.14 & 14.22 & 12.82 & 13.58 \\
\hline 4.76 & 5.05 & 4.42 & 5.09 & 4.16 & 5.93 & 5.39 & 3.77 & 4.14 & 5.15 & 4.28 & 3.30 & 3.95 \\
\hline 2.36 & 10.30 & 9.18 & 10.93 & 6.43 & 11.62 & 10.15 & 7.55 & 6.83 & 11.29 & 10.10 & 6.19 & 8.94 \\
\hline 0.85 & 9.16 & 9.03 & 10.50 & 4.38 & 11.13 & 9.95 & 6.94 & 7.22 & 14.34 & 11.16 & 5.54 & 8.56 \\
\hline 0.74 & 17.94 & 16.99 & 17.05 & 15.13 & 24.92 & 21.82 & 14.65 & 19.16 & 20.85 & 15.53 & 14.55 & 12.90 \\
\hline$<0.74$ & 2.10 & 1.91 & 1.92 & 1.61 & 2.72 & 3.08 & 2.49 & 2.41 & 1.16 & 1.60 & 3.49 & 1.38 \\
\hline R2 & .970 & .991 & .992 & .952 & .965 & .960 & .970 & .965 & .99 & .985 & .972 & .976 \\
\hline$\%<8.5$ & 20 & 19 & 19 & 17 & 28 & 25 & 17 & 22 & 22 & 17 & 18 & 14 \\
\hline$\%<9.5$ & 58 & 52 & 56 & 46 & 72 & 66 & 46 & 52 & 66 & 55 & 44 & 48 \\
\hline P50 & 6.3 & 8.8 & 7.0 & 11.7 & 3.2 & 4.2 & 11.9 & 8.3 & 4.5 & 7.3 & 14.9 & 10.7 \\
\hline $\begin{array}{c}\% \mathrm{RB} \\
\text { survival }\end{array}$ & 0 & 0 & 0 & 2 & 0 & 0 & 2 & 0 & 0 & 0 & 3 & 5 \\
\hline
\end{tabular}

